\title{
Генофонд и селекция абрикоса в Среднем Приамурье
}

Михайличенко О.А., с.н.с.; Юдаева Н.В., м.н.с ФГБУН Хабаровский Федеральный исследовательский иентр Дальневосточного отделения Российской академии наук, Дальневосточный научно-исследовательский институт сельского хозяйства, Хабаровск, Россия. e-mail:lab_plod@mail.ru

Объектами исследований абрикоса являются созданные сорта и формы дальневосточной селекиии, и их гибриды. Детальное изучение биологических и хозяйственно - ценных признаков позволяет оценить их селекиионною значимость в процессе получения новых сортов. Задача селекиионной работы с абрикосом состоит в создании новых сортов, сочетающих в себе высокие хозяйственно - ценные признаки, а также устойчивость к биотическим и абиотическим стрессорам Среднего Приамурья

Ключевые слова: селекиия, абрикос, сортоизучение, гибридизачия, биотические и абиотические стрессоры.

\section{Genepound and apricot selection in the Middle Amur}

Mikhailichenko O.A, Senior Researcher, Yudaeva N.V., Junior Researcher, Federal State Budgetary Institution Khabarovsk Federal Research Center of the Far Eastern Branch of the Russian Academy of Sciences, Far Eastern Agricultural Research Institute Khabarovsk, Russia,Lab_plod@mail.ru

The objects of apricot research are the created varieties and forms of Far Eastern selection, and their hybrids. A detailed study of biological and economically valuable traits allows us to evaluate their breeding importance in the process of obtaining new varieties. The task of breeding work with apricot is to create new varieties that combine high economically valuable traits, as well as resistance to biotic and abiotic stressors of the Middle Amur Region

Key words: selection, apricot, variety study, hybridization, biotic and abiotic stressors.

В дикорастущем состоянии и культуре род абрикоса представлен восьмью видами: абрикос обыкновенный (A. vulgaris), абрикос сибирский (A. sibirica), абрикос маньчжурский (A. manshurica), абрикос Давида (A. davidi$a n a)$, абрикос Ансу (A. ansu), абрикос Муме (A. тите), абрикос тибетский (A. noloserieca) и абрикос волосистоплодный или черный (A. dasyearpa).

Северо-восточная Азия является центром происхождения и одним из древнейших очагов формообразования абрикоса. Здесь в результате совместного произрастания и естественной гибридизации абрикоса обыкновенного с северными видами - маньчжурским, сибирским, Давида - возникли наиболее 
зимостойкие формы, которые послужили исходным материалом для создания культурных сортов абрикоса на Дальнем Востоке [1].

Формирование культурного сортимента абрикоса на Дальнем Востоке началось в 20-х годах прошлого века, но проводилось это на уровне садоводов-любителей. Планомерная работа с абрикосом была развернута в ДВ НИИСХ в 1938 году [2]. Основное ее направление - выведение высокозимостойких и урожайных сортов с товарными плодами хороших вкусовых качеств разных сроков созревания. Работа по созданию местного сортимента абрикоса осуществлялась несколькими путями:

- отбор ценных форм среди сеянцев от свободного опыления восточноазиатской и европейской групп сортов;

- межсортовые скрещивания сортов восточноазиатской группы;

- скрещивание сортов из восточноазиатской группы с европейскими и среднеазиатскими сортами;

- межродовые скрещивания - дальневосточные сливы + восточноазиатские абрикосы.

За истекшие более чем 80 лет произведен большой объем скрещиваний. Селекционерами Г.Т. Казьминым, В.А. Марусичем и Е.Ф. Королевой получено более 20 культурных сортов, среди которых Хабаровский, Академик, Серафим, Ранний Марусича, Подарок БАМу, Петр Комаров и другие [3]. Они до сих пор составляют основу сортимента для Дальнего Востока (табл. 1).

Таблица 1 - Характеристика основных сортов абрикоса, лаборатория плодоводства ДВ НИИСХ

\begin{tabular}{|l|c|c|c|c|c|c|}
\hline \multicolumn{1}{|c|}{ Сорт } & $\begin{array}{c}\text { Скороплод- } \\
\text { ность, год }\end{array}$ & $\begin{array}{c}\text { Сила ро- } \\
\text { ста, м }\end{array}$ & $\begin{array}{c}\text { Сроки со- } \\
\text { зревания }\end{array}$ & $\begin{array}{c}\text { Поражение } \\
\text { болезнями, } \\
\text { балл }\end{array}$ & $\begin{array}{c}\text { Зимостой- } \\
\text { кость }\end{array}$ & $\begin{array}{c}\text { ностай- } \\
\text { ц/га }\end{array}$ \\
\hline Академик & 4 & 4,7 & $5-15.08$ & 2,2 & средняя & 151,8 \\
\hline Амур & 5 & 4,5 & $10-15.08$ & 2,0 & высокая & 133,6 \\
\hline Гритиказ & 4 & 4,7 & $10-15.08$ & 1,0 & высокая & 148,5 \\
\hline Казмар & 4 & 2,9 & $12-19.08$ & 1,5 & высокая & 149,3 \\
\hline Подарок БАМу & 3 & 3,1 & $19.07-5.08$ & 1,0 & высокая & 138,8 \\
\hline Титан & 4 & 3,2 & $4-11.08$ & 1,5 & высокая & 150.9 \\
\hline Хабаровский & 4 & 4,8 & $25.07-5.08$ & 1,5 & высокая & 149,7 \\
\hline
\end{tabular}

Наряду с устойчивостью к неблагоприятным факторам среды, высокой урожайностью, большое значение для сорта абрикоса имеют такие показатели, как масса плода, вес косточки и их соотношение, характер вкуса ядра косточки, что важно учитывать при переработке плодов.

Плоды большинства сортов относятся к крупноплодным. На фоне всех сортов выделяется сорт Академик со средней массой плода 40,5 г (табл. 2). 
Таблица 2 - Технические показатели плодов сортов абрикоса селекции ДВ НИИСХ

\begin{tabular}{|l|c|c|c|c|}
\hline \multirow{2}{*}{ Сорт } & \multicolumn{3}{|c|}{ Показатели плода } & \multirow{2}{*}{$\begin{array}{c}\text { Вкус ядра } \\
\text { косточки }\end{array}$} \\
\cline { 2 - 4 } & $\begin{array}{c}\text { Средняя масса } \\
\text { плодов, г }\end{array}$ & $\begin{array}{c}\text { Макс. масса } \\
\text { плодов, г }\end{array}$ & $\begin{array}{c}\text { Диаметр в двух } \\
\text { плоскостях, мм }\end{array}$ & сладкий \\
\hline Академик & 40.5 & 55,3 & $42 / 37$ & горький \\
\hline Амур & 26,2 & 39,1 & $39 / 38$ & сладкий \\
\hline Гритиказ & 25,8 & 41,0 & $39 / 40$ & сладкий \\
\hline Казмар & 26,0 & 36.0 & $40 / 41$ & сладкий \\
\hline Подарок БАМу & 30,7 & 39,2 & $40 / 39$ & сладкий \\
\hline Титан & 33,2 & 40,5 & $41 / 35$ & сладкий \\
\hline Хабаровский & 31,2 & 45,2 & $40 / 34$ & \\
\hline
\end{tabular}

Объектами исследований абрикоса являются созданные сорта и формы дальневосточной селекции, и их гибриды. Детальное изучение биологических и хозяйственно - ценных признаков позволяет оценить их селекционною значимость в процессе получения новых сортов. Главная роль в селекции принадлежит целенаправленному подбору исходных родительских форм при выведении новых сортов с заданными биологическими и хозяйственно ценными свойствами [4]. Для того, чтобы получить высокозимостойкий сорт абрикоса, необходимо, чтобы исходные родительские сорта, от которых происходят сеянцы, обладали прежде всего высокой устойчивостью к биотическим и абиотическим стрессорам Среднего Приамурья, в сочетании с урожайностью и качественными товарными плодами, компактностью деревьев для использования в садах интенсивного типа. Задачу можно решить путем создания и накопления гибридного материала с целью дальнейшего его использования в селекции и гибридизации лучших по отдельным признакам сеянцев с сортами улучшителями или друг с другом [5]. Наиболее эффективным методом при работе по селекции абрикоса мы считаем метод аналитической селекции, массовый отбор сеянцев, полученных от свободного опыления.

Лучшим подвоем для дальневосточных сортов абрикоса, по нашему мнению, является - абрикос маньчжурский. Абрикос маньчжурский характеризуется высокой зимостойкостью и очень коротким периодом покоя, который наступает в связи с резким похолоданием в осенне-зимний период. В условиях муссонного климата Дальнего Востока, где в течение зимы удерживается низкая температура без оттепелей, не наблюдается подмерзания почек и цветков от возвратных весенних заморозков. Не бывает и подопревания коры у корневой шейки.

За последние четыре года генофонд абрикоса лаборатории плодоводства ДВ НИИСХ пополнился тремя новыми сортами по своим характеристикам отвечающим современным требованиям к абрикосу для Дальневосточного региона. 
Гритиказ - Сорт включен в Госреестр по Дальневосточному (12) региону. Патент № 9979, 23.01.2019 г. Универсальный, позднего срока созревания.

Дерево большое, с раскидистой кроной средней густоты. В плодоношение вступает на 5-ый год. Плоды плоской формы, с красноватой покровной окраской, средней массой 25,8 г. Кожица слабо опушена. Мякоть желтая, волокнистая, кисло-сладкого вкуса. Дегустационная оценка - 4,5 балла. В плодах содержится: сухих веществ $11,1 \%$, сахара $8,5 \%$, кислоты $1,8 \%$, витамина С 7,7 мг/\%. Средняя урожайность - 148 ц/га. Зимостойкость высокая.

Казмар - В 2019 году сорт предан на Государственное сортоиспытание. Универсальный, позднего срока созревания. Дерево средних размеров с разряженной кроной. В плодоношение сорт вступает на третий год. Форма плода плоская, средний вес плодов 26 г, (максимальный 36 г), окраска плода желто - оранжевая, вкус кисло-сладкий. Дегустационная оценка - 4,7 балла. В плодах содержится: сухих веществ $11,3 \%$, сахара $8,7 \%$, кислоты $1,8 \%$, витамина С 7,7 мг/\%. Средняя урожайность - 149,3 ц/га. Зимостойкость высокая.

Титан - 2016 году сорт предан на Государственное сортоиспытание. Универсальный, среднего срока созревания. Дерево средней силы роста, крона густая, округло-вытянутая. В плодоношение вступает на третий год. Средняя масса плода 33,2 г, (максимальная 40,5 г). Форма округлая. Окраска плода желтая, покровная красноватая. Мякоть нежная, оранжевая от кожицы, сочная, освежающая, приятного кисло-сладкого вкуса. Дегустационная оценка - 4,8 балла. В плодах содержится: сухих веществ 10,1 \%, сахара 9,1 $\%$, кислоты $1,8 \%$, витамина С 7,7 мг/\%. Средняя урожайность - 150,9 ц/га. Зимостойкость сорта высокая.

\section{Список литературы}

1. Асеева, Т.А. Энциклопедия садоводства Приамурья / Т.А. Асеева, О.А. Михайличенко, Е.С. Тихомирова - Хабаровск: изд-во Тихоокеанского гос. ун-та, 2015. -243 с.

2. Казьмин Г.Т. Дальневосточный абрикос / Г. Т. Казьмин, В. А. Марусич. - 2-е изд., перераб. и доп. - Хабаровск: Кн. изд-во, 1989. - 157 с.

3. Царенко, В.П. История садоводства на Дальнем Востоке / В.П. Царенко, Н.А. Царенко. - Владивосток: Морской гос. ун-т, 2017. - 300 с.

4. Исаев, С.И. Современные методы селекции плодовых и ягодных культур / С.И. Исаев. - Москва: «Знания», 1979. - 302 с.

5. Матюнин, М.Н. Биологические особенности и селекция косточковых культур в Горном Алтае / М.Н. Матюнин. - Новосибирск: 2016. - 344 с. 